Lang. Soc. 1, 121-130. Printed in Great Britain

\title{
Variation and variables in religious glossolalia
}

\author{
WILLIAM J. SAMARIN \\ Department of Anthropology, University of Toronto
}

\section{ABSTRACT}

Psychopathological explanations oversimplify religious glossolalia. An analysis of the use of glossolalia reveals that the speaker manipulates linguistic variables with considerable delicacy in response to role, purpose of the speech act, and setting of the speech act. Examined from a cultural point of view, glossolalia is another 'language' in the Pentecostalists' linguistic repertoire. (Glossolalia, Pentecostalism, speech pathologies, paralinguistics, language of religion.)

An unfortunate inattention to linguistic and cultural facts is responsible for a gross misunderstanding of a persistent human trait: the use of anomalous speech in culturally meaningful ways. Sometimes the failure is greatest when linguistic facts are slighted and sometimes when they are cultural. The result is that although there is a sizable (but by no means adequate) body of observations on miscellaneous forms of speech (such as baby talk, disguised speech, secret languages, spells and incantations, etc.), there is yet no unified treatment that would relate 'normal' to 'anomalous' speech. This is a serious lack in our description of human behavior, because it indicates a failure to comprehend a significant element in the unity of mankind.

This paper is no sketch or outline of the work that we anticipate. That, indeed, may be no single volume but a whole shelf of books and articles. This study is intended, however, to suggest the possibilities that lie before us.

Glossolalia is best known as a Christian phenomenon. In that religion, it more commonly goes by the name 'speaking in tongues'. But both expressions glossolalia and tongues - have been used by psychologists, anthropologists, and linguists to identify a wide range of anomalous speech, many of which have very little in common. For example, to say that glossolalic utterances vary 'all the way from a series of gurgles and grunts to deviant forms of normal language' (Burling 1970: 152 ) is to say only that they are vocal in nature. This comes from resigning oneself to the belief that 'it is difficult to make generalizations about any internal form or structure that glossolalic utterances may have' (ibid.: I 52-3).

[1] A revised version of a paper given at the 69th Annual Meeting of the American Anthropological Association, San Diego, California, 22 November 1970. The original title was 'The glossolalist's "grammar of use"'. 


\section{LANGUAGE IN SOCIETY}

A single article, in my opinion, is largely responsible for the widespread confusion about 'glossolalia' so called. This is May's article (1956), cited in Burling's work. It is hardly more than a survey of the uses of the term glossolalia (and its equivalent). May provides no linguistic evidence that there is a single linguistic phenomenon, nor does he argue convincingly on nonlinguistic grounds that a single term accurately unifies all his various speech forms.

When we examine a wide variety of samples of Christian glossolalia, we find significant patterns recurring. This observation is based on an analysis of hours of tape-recorded texts, most of them from native speakers of English and most of them members of the neo-Pentecostal movement. This movement shares much of the doctrine of traditional Pentecostalism (for example, that a Christian needs a special filling of, or baptism in, the Holy Spirit and that this experience is manifested in divine speech - namely, glossolalia), but its members stay within their own churches and denominations, most of them middle or upper middle class. It cuts across sectarian lines, even incorporating at least 30,000 Roman Catholics in North America, and is not identified with any single organization. The most important one, however, is the Full Gospel Businessmen's Fellowship International (Los Angeles, California). I have also been a participant-observer in traditional Pentecostal churches, both lower and middle class, and in one meeting of snake cultists in West Virginia where tongues were also used (see La Barre and Adair for the latter). In addition, I have heard glossolalia among native speakers of Russian (Molokans in Los Angeles, see Berokoff), Dutch (traditional Pentecostalists in The Hague), and Spanish (Puerto Rican members of an Assembly of God church in the Bronx, New York).

A thorough linguistic characterization of glossolalia is presented in Tongues of Men and Angels (Samarin, to appear) and summary ones in Samarin (1968, 1971). Student analyses are found in Jaquith (1967), Motley (1967), and Wolfram (1966). In all of these are found samples of glossolalic discourse. But see also below.

If there has been error in comprehending too much under the rubric of glossolalia, there has also been error in not comprehending enough. Christian glossolalia, as I have tried to show elsewhere (Samarin $1970 a$ ) is continuous with other forms of pseudolanguage. Since they are used for different purposes than in the Christian religion, they will not be discussed here (but see Samarin, 1972). They all can be covered by a single definition of glossolalia: Unintelligible extemporaneous post-babbling speech that exhibits superficial phonologic similarity to language without having consistent syntagmatic structure and that is not systematically derived from or related to known languages. In this paper we limit ourselves to contemporary Christian glossolalia, because we want to specify its cultural context.

PSYCHOLOGICAL EXPLANATIONS OF GLOSSOLALIA

If people have erred in looking too casually at the verbal data of glossolalia, they 
VARIATION AND VARIABLES IN RELIGIOUS GLOSSOLALIA

have also paid too little attention to glossolalic speech acts and to the system of beliefs that motivate them. This is why psychological explanations have been more common than cultural ones: glossolalists have been treated as abnormal.

Of the same ilk is the explanation that glossolalia is nothing more than an artifact of trance. This is the position taken by Goodman in a paper read at the Annual Meeting of the American Anthropological Association in 1968, whose view is reflected in Burling (1970: $15 \mathrm{I}$ ). This view can be rejected simply on the basis of a critical assessment of the description (Goodman 1969a, 1969b) which provides no strong support for this explanation and reveals a naïve understanding of language and language analysis. External evidence could also be cited to demonstrate that in fact an altered state of consciousness rarely accompanies the production of glossolalia among Christians.

Psychopathological explanations for engaging in glossolalia have been so common that they are largely taken for granted. Laffal, on the basis of experience with one schizophrenic patient, accounts for glossolalia in terms of repression (1965:88). Oates says that it is the result of 'emotional deprivation' whereby 'religious feelings, aspirations, and ideas' are expressed in a 'sudden chaotic breakthrough' (1968: 4I, 48, 97). Another view is that glossolalia is regressive in the sense that it serves as a means of 'restoring infantile megalomania' and of expressing feelings of omnipotence or egocentricity and also frustration over unfulfilled desires (shared by Oman 1963: 49; Oates 1967: 96; and Worsley 1957: 247). Other views and variations of those mentioned here, are surveyed in Tongues of Men and Angels and in Hine (1969).

When we look at the culture of the glossolalist, we find no reason to judge him abnormal. Like other Christians, he believes that the Holy Spirit dwells in him and motivates him. But Christians differ as to when this divine residence begins and how it is manifested. In the Pentecostal view the Holy Spirit comes in a rush, a 'baptism', and this presence is manifested physically through the baptized person.

There is much more than this to the belief system, of course. The point being made here is simply that it is cultural factors that elicit certain kinds of speech acts, whether they be 'normal' or 'anomalous', in one normal language or another (such as English or Spanish), or in one variety or another (intimate or formal). Therefore, regardless of what a glossolalist's speech may sound like and regardless of what use he may make of his tongues, his becoming a member of the Pentecostal subculture determines his engaging in glossolalic speech events. (It is irrelevant at this point that in some groups there are people who never talk in tongues. The system of belief accommodates these deviants as much as 'normal' society accommodates its own deviants.)

Once a person has become a full-fledged member of the subculture (and 'receiving the gift' of tongues can be considered part of the 'initiation rite', we might call it), he can go on to develop skill in the production of glossolalia and in a 


\section{LANGUAGE IN SOCIETY}

more refined control of its use. In effect, he learns to talk. As it is with the child, so it is with the glossolalist: while he improves his physiologic control of speech, so he also improves his understanding of how his environment impinges on his speech. In the same way that a child learns to say his prayers in a low voice, because that is how one talks to God, a glossolalist adjusts his speech according to social requirements.

\section{FACTORS THAT DETERMINE GLOSSOLALIC UTTERANCES}

The factors that are most important in determining the feature of a glossolalic speech act are three: namely, the role of the speaker, the purpose of the speech act, and the setting or context of the speech act. Indeed, these factors are functional in affecting the speaker's choice between natural language (say, English) and glossolalia in the same way that they (among other things) affect language switching among bilinguals. Like the bilingual, the glossolalist has a repertoire of languages from which he can select according to his and the Pentecostal society's needs. Moreover, like the normal speaker of language, the tongue speaker has varieties of glossas (a neologism for glossolalic 'languages') that are analogous to 'registers' or functional types.

\section{Role of speaker}

It makes a difference to the production of glossolalia whether the speaker is a leader (clerical or lay) in the group or just an ordinary member. For example, it is the leaders who generally assume the privilege of making pronouncements in glossolalia (that is, giving messages, which shall be discussed shortly). And in the setting of a public occasion (where the number of participants is less important than the understood nature of the event), even glossolalic prayer is seen as the function of recognized (or self-recognized) leaders. The function of role in the exercise of glossolalic speech is implied in the regulations laid down by glossolalist leaders like Rev. Oral Roberts (for example, 'The Lord may not manifest a [spiritual or charismatic] gift in us because of our worthiness but we have to be worthy in our character to exercise it effectively!' [1964: 65]). The 'worthies', as personal observation reveals, turn out to be the leading figures in the group. (Similar observations are made by Calley for West Indians and by Willems for Pentecostals in South America.) In other words, in spite of the fact that Pentecostals believe that the Holy Spirit does what he wants, his activities are channeled through social structure.

Purpose of the speech act

Two functions of glossolalia are recognized by Pentecostals: praying and making divine pronouncements. The first is open to everyone, and it is in fact encouraged as a means for 'edification'. Among neo-Pentecostals this is the most common use; 
VARIATION AND VARIABLES IN RELIGIOUS GLOSSOLALIA

indeed, most people engage in glossolalia only for prayer. Moreover, they use it in private or only in intimate (that is, nonpublic) settings. Making pronouncements is sometimes called the 'gift of tongues', because a speaker is 'gifted' or selected by God on his own initiative to give a message to the assembled body. Since the utterance is unintelligible, there must always be an 'interpretation' (a kind of pseudotranslation) in natural language. This too is a charismatic act; so there are people with the gift of interpretation. It turns out that these people also (as one might expect) are usually leaders in the group. A third function has not been integrated into Pentecostal doctrine, probably because it finds no biblical justification. The others do. I call it simply reinforcement. It occurs in a public setting when a participant ejaculates in glossolalia to give approval to what someone has just said (in normal language) or to something that has just happened. It is comparable to the use of 'Amen!' 'That's right!' and similar phrases in Pentecostal culture and to 'Right on!' in American Black culture. Supplementing my own observations are statements like the following one from a former Pentecostal that indicates the same kind of function for glossolalia: 'After [the pastor] had concluded his powerful sermon and when one of the old-time members put a seal of approval on it by bursting out in tongues . . ' (Bach 1970: 36).

It is these functions of glossolalia, among other things, that demonstrate quite clearly that pseudolanguage is being used just as another linguistic 'code' in the inventory - or repertoire - of the Pentecostal subculture. A glossa is just another language to its speaker. So strong is this belief that it results in inconsistency: although the speaker is supposed to be nothing but a channel for a divine utterance, as in the giving of messages, he is something else in prayer - for glossolalists certainly do not believe that God is using them to talk to himself!

\section{Setting of the speech act}

The setting must be described in terms of many variables, most of which are not foreign to any observer of religion. In one dimension, three have already been mentioned: public, intimate, and private. That is, it makes a difference how one uses glossolalia and what form it takes, depending on the nature of the occasion for the speech act. So a person does not give a message in tongues when he is alone in prayer. And although he may report to his group that God had revealed such-and-such to him in tongues (he being his own interpreter), we can suppose that the nature of the discourse would be quite different from one given at a meeting with 500 people in attendance. It would have a different selection of sounds and syllables; its melodic pattern would be different; and it would be delivered in a different manner - both kinesically and paralinguistically.

These, then, are the determinants of the glossolalic speech event. Their effect is seen on both vocal and nonvocal behavior. Thus, when a person makes a pronouncement in tongues, he behaves differently from when he prays in a 
small group. (Some people, of course, make public tongue praying look and sound like preaching, but this is also true of a lot of natural-language praying, certainly among many Protestants if not others also.)

This section can be summarized and illustrated by an account of the use of glossolalia as written by faith-healer Oral Roberts:

The meeting was in the home of a friend of mine and it was so packed that many had to sit on the floor ... I noticed one of the young ladies seemed to be under a heavy anointing [physically manifesting deep emotions and under divine influence]. I could tell she was striving almost desperately to exercise self-control. . . The very moment I ceased talking she reached her hand forth, touched me and said, 'May I, please?' . . . I said [to her], 'Please do.' With her eyes closed and so quietly her voice was barely discernible through the room, she began to exercise a gift of tongues [that is, make a pronouncement]. It was a voice of beseeching at first, then it changed to a triumphant note. Just as quietly she gave the interpretation. God gave us a beautiful and powerful confirmation of the doctrine of healing [which was the topic of the group's discussion]. People left there that night knowing the Spirit had illuminated their minds and hearts to have compassion for the healing of the sick (1964: 63).

Notice how Roberts identifies the harmony of the way the girl exercised her charismatic gifts with the final 'meaning' of the whole event: the group shared a quiet confidence.

\section{VOCAL EFFECTS OF SOCIO-CULTURAL FACTORS}

The phenomena that respond to role, purpose, and setting comprise those that one would expect for any discourse in language - except for a grammaticalsemantic component. This leaves us with phenomena that many linguists would consider nonlinguistic, because not accountable in terms of usual grammatical theory. Indeed, there are no systematic correlations between form and meaning (signifians, signifié) or between something in the discourse and something denoted by it. (The exceptions consist of small stretches of speech that speakers associate with specific religious experiences, hence take on their 'meaning', such as joy or praise, and others that are taken to be names for the deity. Some people also recognize that they open and close their prayers in formulaic ways, with or without a natural-language $A m e n$.) The phonological output is a largely random one, drawing upon the speaker's stored resources of natural-language phonological shapes, in the way musical scanning is (as in la diri di da dudu).

It is the outward form, therefore, that is most responsive to social requirements. The most obvious variables are duration, speed, and volume. The length or duration of a glossolalic discourse depends on, for example, what it is used for. 
VARIATION AND VARIABLES IN RELIGIOUS GLOSSOLALIA

Ejaculatory reinforcements are shorter than messages. When people are praying 'round the circle', each one taking his turn, their prayers in tongues - as when they pray in natural language - tend to be of the same duration, as if they had all agreed to divide the total amount of time devoted to prayer equally. Public messages never seem to be as long as sermons or testimonies, but they have their own common duration. Speed and volume are so affected by other factors. Since a message is given with the conviction that it contains important information from God, the speech is faster (perhaps because the message is urgent) and the volume greater. Many other characteristics could be mentioned. Some of them might also be considered paralinguistic. Thus, a message of assurance sounds different from a message of denunciation; a prayer of praise sounds different from a supplication.

But even in its inner form a glossolalic discourse reflects its use. Although a person does not consciously select the vowels and consonants and the types of syllables out of which he constructs his utterances, there is obviously some kind of selection at work. This is in addition to negative selection, which is avoidance. Thus, a native speaker of English seems to avoid the voiceless and voiced interdental fricatives 'th' [ $\theta]$ and ' $d h$ ' [d], probably because they make his pseudolanguage sound too much like his native language. And a speaker of one of the easily recognized regional dialects in the United States, like 'Southern', seems to avoid the diphthongs that characterize that speech. Of more interest to us, however, is covariant selection: that is, where one set of features is associated with, say, praising God, and another with exorcizing evil spirits. This kind of more-orless systematic variation is recognized even by some of my informants. They are naive in the way they make their reports, but their statements are convincing. (Most of these are found in responses to my questionnaire which was filled out by 84 tongue speakers from all over North America, both traditional Pentecostals and non-Pentecostals. The informant population is described in Samarin (1970b), in which also is found the full text of the questionnaire.)

It is well known, of course, that glossolalists believe that some people speak different (glossolalic) languages, and it is indeed true that these glossas are sometimes quite different from each other. (But the simple texts given below show how similar they can also be.) What is significant for our present discussion is that the glossolalist changes languages to suit his immediate need: for example, giving a public pronouncement or uttering a secret prayer.

\section{SUMMARY}

This paper makes the strong assertion that glossolalia is an additional linguistic code in the Pentecostal's total repertoire and that it functions to define and express the domain of experience he considers religion. It is for him religious language par excellence. Like normal language, moreover, glossolalia is sensitive 


\section{LANGUAGE IN SOCIETY}

to extralinguistic variables, so sensitive in fact that its own set of subcodes emerges in response to situated elicitation.

This paper further rejects the notion that glossolalia is an artifact of dissociative states. The tongue speaker is most often a sophisticated user of speech, selecting this and that variable with considerable delicacy. He may, of course, fall into trance (but this is more likely for traditional Pentecostals than neoPentecostals, in any case - for cultural not psychological reasons), but then his performance will, I believe, be less nuanced.

Finally, this paper suggests that glossolalia is best understood - it makes sense - only when one enters the Pentecostal's world and sees it from his point of view.

\section{SAMPLE TEXTS OF RELIGIOUS GLOSSOLALIA}

The following two texts are typical of neo-Pentecostal glossolalic discourse, whether they be messages or prayers. The speaker is an American male in his late thirties. These are prayers recorded, along with all the others, at a prayer session consisting of like-minded individuals with their full knowledge. Although no outsiders were present, the recording was made in the hope that it would help others understand the charismatic movement, including glossolalia.

The transcription used here is a 'broad' phonetic one. For example, no distinctions are made between a range of raised central vowels, hence only [ə] is recorded. The letter ' $r$ ' represents a single-tap flapped consonant (not distinguished for voicing) and ' $h$ ' is the voiced counterpart of ' $h$ ' (like the sound in some pronunciations of Sahara); acute and grave accents indicate primary and secondary stresses respectively; but stress - along with 'word' division, indicated by space - is difficult to identify consistently. A syllable consists of a vowel nucleus, plus or minus a consonant onset and coda. The phonetics of these texts is basically that of English, the native language of the speaker. Therefore, the vowels $[i, a, o]$ tend to be glided, especially in stressed syllables; for example [do] is like dough.

These two texts are very similar in phonological inventory. One of the differences is that $A$ has [f] but no [p] whereas $B$ has just the reverse. There are also differences in frequencies of sounds: for example, $B$ has very few aspirated ['] voiceless stops. Even more striking, but not apparent in this transcription, is the fact that the vowels of $B$ are only slightly diphthongal by comparison with those of $A$ and that there are differences in rhythm and pitch: $A$ tends to be stresstimed, B syllable-timed; in A pitch is distributed in intonational contours whereas in $B$ the impression one gets is that of a register-type tone language. It is these kinds of differences that characterize varieties of tongues as described above. In this instance the speaker believes that he is using two languages. Before uttering the second prayer he made the following statement: 'God has given me different manifestations of the Spirit at different times ... I'm going to ask the Lord to 


\section{VARIATION AND VARIABLES IN RELIGIOUS GLOSSOLALIA}

give me another language that's entirely different from the language I just spoke [namely, Text A] . . "Father, we ask you now, that you will . . . grant this manifestation of thy Holy Spirit in an entirely different language.",

Prayer in glossolalic language $A$ (43 sec.): k'olamàsiándo labok'à tohoriomàsí làmo siándo labok'à t'ahàndoria lamo siàndo k'oləmàsí làbosiándo lakat'ándori lamo siàmbəbə k'ət'ándo lamá fià lama fiàndoriək'o labok'an doriasàndó làmo siándoriako làbo siá làmo siandó làbək'án dorià lamà fiá lama fiàndolok'oləməbəbəsí ləbo siàndó lamà fiat'andorià lamok'áyəmasi labo siàndó.

Prayer in glossolalic language $B$ (38 sec.): mabasándo kotándəhokət'àmbasí lamáhka kàndəhondo lahàmbakàhiamàsí məhàma kəttəhándo kəhómasi màkətahándo kahámbasì mósiahànto kohòmbà mahápəkəhàndohài làmbòsìhàndò kohómbà làhambakatì yahàməsí mópəsiyàndo kotáhando làmasì papakàndo lámasià làšohóndo kotambà babàsì lamasapj̀nmotiakó labàsandó másiàndo k'at'àndorí.

\section{REFERENCES}

Adair, P. Holy Ghost People [sound film]. Produced by Blair Boyd. Thistle Films.

Bach, M. (1970). The inner ecstasy: the power and the glory of speaking in tongues. New York: World Publishing Company.

Berokoff, J. K. (1969). Molokans in America. Los Angeles, privately published.

Burling, R. (1970). Man's many voices. New York: Holt, Rinehart and Winston.

Calley, M. J. C. (1965). God's people: West Indian Pentecostal sects in England. London: Oxford University Press.

Goodman, F. D. (r969a). Phonetic analysis of glossolalia in four cultural settings. $\mathfrak{f n l}_{n}$ Scientific Study of Religion 8. 227-39.

- $(1969 b)$. Glossolalia: speaking in tongues in four cultural settings. Confinia psychiatrica I2. I $13-29$.

Hine, V. H. (r969). Non-pathological Pentecostal glossolalia: a summary of relevant psychological literature. Inl Scientific Study of Religion 8. 2 I 1-26.

Jaquith, J. R. (1967). Toward a typology of formal communicative behavior: glossolalia. AnL 9 (8): I-8.

La Barre, W. (I962). They shall take up serpents: psychology of the southern snake-handling cult. Minneapolis: University of Minnesota Press.

Laffal, J. (1965). Pathological and normal language. New York: Atherton Press.

May, L. C. (1956). A survey of glossolalia and related phenomena in non-Christian religions. $\operatorname{AmA}$ 58. $75-96$.

Motley, M. (1967). Glossolalia: analyses of selected aspects of phonology and morphology (Unpublished M.A. thesis). Austin: The University of Texas.

Oates, W. E. (1968). The Holy Spirit in five worlds. New York: Association Press.

Oman, J. B. (1963). On 'speaking in tongues': a psychological analysis. Pastoral Psychology 14 (1 39): 48-5 I.

Roberts, O. (1964). The baptism with the Holy Spirit and the value of speaking in tongues today. Tulsa: privately published.

Samarin, W. J. (1968). The linguisticality of glossolalia. Hartford Quarterly (Hartford Seminary Foundation, Hartford, Conn.) 8 (4): 49-75.

- (1969a). The forms and functions of nonsense language. Linguistics 50. 70-74. 


\section{LANGUAGE IN SOCIETY}

(1969b). Glossolalia as learned behavior. Canad. Inl Theology 15. 60-4.

(1970a). Glossolalia as regressive speech. Paper presented at the Summer Meeting of the Linguistic Society of America, Columbus, Ohio.

(1970b). Language in resocialization. Practical Anthropology 17. 269-79.

(1971). Evolution in glossolalic private language. $A n L$ 13(2): $55-67$.

(1972), Tongues of men and angels. New York: The Macmillan Co.

Willems, E. (1967). Validation of authority in Pentecostal sects of Chile and Brazil. Fnl Scientific Study of Religion 6. 254-8.

Wolfram, W. A. (1966). The sociolinguistics of glossolalia (Unpublished M.A. thesis). Hartford, Conn.: Hartford Seminary Foundation.

Worsley, P. (1957). The trumpet shall sound. London: MacGibbon \& Kee. 